\title{
PENYULUHAN PENANGANAN PENYAKIT IKAN DENGAN MEMANFAATKAN HERBAL PADA PEMBUDIDAYA IKAN DI DANAU BATUR, BALI
}

\author{
E.W. Suryaningtyas ${ }^{1}$, I.W. Restu' ${ }^{2}$ I.Y.P. Perwira ${ }^{3}$ I.W.G.A. Karang ${ }^{4}$, \\ I.G.B.S. Dharma ${ }^{5}$ dan E. Faiqoh ${ }^{6}$
}

\begin{abstract}
ABSTRAK
Budidaya ikan di karamba jaring apung (KJA) di Danau Batur telah lama dilakukan oleh penduduk asli di sekitar Danau Batur. Komoditi ikan yang dibudidayakan adalah ikan nila. Kendala utama pembudidaya adalah parasit dan penyakit yang menyerang ikan nila. Selama ini untuk mengobati penyakit ikan nila menggunakan bahan kimia yang bisa mengakibatkan pencemaran lingkungan dan manusia yang mengkonsumsi ikan. Alternatif yang tepat adalah penggunaan herbal untuk pencegahan dan pengobatan parasit dan penyakit ikan nila di Danau Batur. Tujuan pengabdian ini adalah untuk memberikan pengetahuan dan keterampilan pada pembudidaya ikan di Danau Batur tentang manfaat tanaman herbal dalam penanganan parasit dan penyakit ikan. Jenis herbal yang bisa digunakan untuk pencegahan dan pengobatan penyakit ikan nila adalah bawang putih, kunyit, sirih dan daun pepaya. Metode yang digunakan adalah penyuluhan dan sosialisasi dengan penyebaran leaflet pada pembudidaya ikan. Hasil kegiatan menunjukkan $90 \%$ peserta memahami materi yang diberikan, hal ini tampak pada respon pertanyaan dan keinginan untuk mempraktekkan pengetahuan tersebut. Kegiatan pengabdian ini dapat disimpulkan pembudidaya sangat tertarik pada pemanfaatan herbal dalam penanganan penyakit ikan nila.
\end{abstract}

Kata kunci : budidaya ikan, ikan nila, Danau Batur, parasit, penyakit, herbal

\begin{abstract}
The aquacultue with floating net cages in Batur Lake has long been done by indigenous people around Batur Lake. Major commodities aquaculture is tilapia. The main problems of the fish farmers are the parasites and diseases that attack the tilapia. During this time to treat the disease tilapia using chemicals that can lead to environmental pollution and humans who consume fish. The right alternative is the use of herbs for the prevention and treatment of parasites and tilapia disease in Batur Lake. The purpose of this counseling is to provide knowledge and skills to the fish farmers in Batur Lake about the benefits of herbs in the handling of fish parasites and diseases. Types of herbs that can be used for the prevention and treatment of tilapia disease are garlic, turmeric (Curcuma longa), betel (Piper betle) leaf and papaya leaf. The method used is counseling and socialization with the spread of leaflets on fish farmers. The results show $90 \%$ of the participants understand with matery, it appears in the response questions and the desire to practice that knowledge. This counseling activity can be concluded that the fish farmers are very interested in the utilization of herbs in the handling of tilapia diseases.
\end{abstract}

Keywords: aquaculture, tilapia, Batur Lake, parasites, diseases, herbs

\footnotetext{
1,2,3 Staf Pengajar Program Studi Manajemen Sumberdaya Perairan, Fakultas Kelautan dan Perikanan, Universitas Udayana, Email: endangwulandari@unud.ac.id 4,5,6 Staf Pengajar Program Studi Ilmu Kelautan, Fakultas Kelautan dan Perikanan, Universitas Udayana
} 


\section{PENDAHULUAN}

Produk unggulan yang dikembangkan di Danau Batur, Kec. Kintamani, Bangli adalah ikan nila yang dibudidayakan menggunakan Karamba Jaring Apung (KJA). Sentra produksi ikan nila dengan metode KJA adalah kabupaten Bangli sedangkan dengan metode kolam adalah kabupaten Tabanan. Alasan pemilihan komoditas nila dikarenakan masyarakat sekitar lebih menyukai ikan nila dibandingkan dengan ikan lainnya, memiliki nilai yang ekonomis, mudah dipelihara dan memiliki prospek pemasaran yang cukup tinggi. Konsep satu kawasan, satu produk yang diterapkan pemerintah Bali semakin menegaskan mengapa komoditas nila saja yang dikembangkan.

Sampai tahun 2012 jumlah KJA sekitar 560 yang dikelola oleh 950 orang pembudidaya ikan. Masing-masing KJA terdiri atas 9 petak dan tersebar di beberapa tempat yaitu Desa Kedisan dan Toya Bungkah (1.200-1.300 petak), serta Trunyan, Buahan, dan Songan (1.000 petak). Semua tempat tersebut berlokasi di tepian Danau Batur. Pemasaran ikan nila segar memasok sejumlah restoran, pemancingan, serta pasar modern dan tradisional di Bangli, Denpasar dan Badung.

Salah satu kendala dalam usaha pengembangan budidaya ikan nila adalah terjadinya serangan hama dan penyakit ikan. Berkembangnya penyakit ikan dalam proses budidaya ikan pada dasarnya disebabkan terjadinya ketidak seimbangan interaksi faktor lingkungan, mikroba air dan ikan. Ketidakseimbangan ini dapat disebabkan perubahan kualitas air menjadi buruk sehingga mikroba pathogen berkembang dalam air dan menyerang ikan budidaya (Kordi, 2009). Selama ini pencegahan terhadap serangan bakteri pada umumnya dilakukan dengan pemberian antibiotik dan bahan kimia. Akan tetapi, penggunaan antibiotik dapat menimbulkan efek samping bagi patogen itu sendiri maupun terhadap ikan yang dipelihara. Pemberian antibiotik secara terus menerus dengan dosis/konsentrasi yang kurang/tidak tepat, akan menimbulkan masalah baru yaitu meningkatnya resistensi mikroorganisme terhadap bahan tersebut. Selain itu, residu dari antibiotik dapat mencemari lingkungan perairan yang mengakibatkan kualitas air menjadi turun dan manusia yang mengonsumsinya (Aldermann, 2004).

Berkaitan dengan permasalahan tersebut, perlu ada alternatif bahan obat yang lebih aman yang dapat digunakan dalam pengendalian penyakit ikan. Salah satu alternatifnya adalah dengan menggunakan tumbuhan herbal yang bersifat anti parasit, anti jamur, anti bakteri, dan anti viral. Beberapa keuntungan menggunakan tumbuhan obat tradisional antara lain relatif lebih aman, mudah diperoleh, murah, tidak menimbulkan resistensi, dan relatif tidak berbahaya terhadap lingkungan sekitarnya.

Beberapa tumbuhan obat tradisional yang diketahui dapat dimanfaatkan dalam pencegahan berbagai agen penyebab penyakit ikan adalah sirih (Piper betle L.) dan bawang putih (Allium sativum). Daun sirih diketahui berdaya antioksidasi, antiseptik, bakterisida, dan fungisida. Haryani dkk, (2012) membuktikan bahwa dengan merendam ikan mas koki selama 48 jam dengan dosis 1245 daun pepaya memberikan hasil kelangsungan hidup sebesar 99\%. Bawang putih mempunyai salah satu bahan aktif yaitu allicin, yang merupakan suatu senyawa yang terdiri atas $40 \%$ sulfur, tanpa nitrogen maupun halogen dan mempunyai sifat antibakteri. Berdasarkan penelitian Lengka dkk, (2013), bawang putih dengan dosis 30g/kg pakan dan diberikan selama satu bulan efektif meningkatkan respon imun non spesifik dan pertumbuhan mas. Sedangkan Fakhrizal (2010) menyatakan bahwa dosis 30\% ekstrak bawang putih dengan lama perendaman selama 1 menit dapat mematikan kutu ikan (Argulus sp.) pada ikan mas koki.

Danau Batur merupakan sentra budidaya ikan air tawar, terutama ikan nila. Pengembangan perikanan danau Batur mempunyai arti yang strategis dalam rangka pemberdayaan ekonomi masyarakat sekitar danau, sehingga perlu upaya untuk meningkatkan kuantitas dan kualitas 
budidaya ikan nila. Namun pembudidaya ikan masih belum mengetahui cara aplikasi penggunaan tanaman herbal dalam budidaya yang lebih aman, murah, praktis dan efisien dalam penggunaannya. Oleh karena perlu adanya penyuluhan untuk memberikan pengetahuan dan keterampilan pada pembudidaya ikan di Danau Batur, Kec. Kintamani, Kab. Bangli tentang manfaat tanaman herbal dalam penanganan parasit dan penyakit ikan.

\section{METODE PELAKSANAAN}

Kegiatan pengabdian dilaksanaan melalui penyuluhan dengan cara memberikan pemahaman tentang dampak negatif pemakaian bahan kimia dan antibiotik untuk mengobati penyakit ikan, dan memberikan pengetahuan tentang keuntungan yang akan diperoleh dengan penggunaan tanaman herbal dalam penanganan penyakit ikan. Kegiatan penyuluhan juga disosialisasikan dengan penyebaran leaflet untuk pembudidaya ikan.

\section{HASIL DAN PEMBAHASAN}

Pelaksanaan kegiatan pengabdian pada masyarakat dimulai dari persiapan, yang meliputi persiapan konsep acara penyuluhan, penyusunan materi penyuluhan, persiapan tempat dan peralatan, sosialisasi acara kepada khalayak sasaran. Konsep acara penyuluhan dimulai dengan pemaparan materi kemudian dilanjutkan dengan sesi tanya jawab. Penyusunan materi penyuluhan disesuaikan dengan permasalahan yang sering dihadapi oleh pembudidaya ikan nila, yang berkaitan dengan penyakit ikan nila di karamba jaring apung (KJA). Persiapan tempat dan peralatan untuk kegiatan penyuluhan menunggu ijin dari Kepala Desa Songan, dengan mengirimkan surat pemberitahuan dan permohonan ijin melaksanakan penyuluhan di desa tersebut. Selain mengirimkan surat kapada Kepada Desa, surat permohonan ijin tempat juga dikirimkan pada Kepala Sekolah SMK Negeri 2 Kintamani. Sosialisasi pelaksanaan kegiatan pengabdian kepada pembudidaya ikan dilakukan dua minggu sebelum pelaksanaan kegiatan. Sasaran pengabdian adalah ketua dan anggota kelompok pembudidaya ikan nila di Danau Batur.

Kegiatan pengabdian pada masyarakat telah dilaksanakan pada hari Sabtu, 30 Agustus 2014. Bertempat di kelas SMK Negeri 2 Kintamani. Peserta yang mengikuti penyuluhan sebanyak 30 orang, yang terdiri dari pembudidaya ikan nila, guru SMK Negeri 2 Kintamani, dan siswa SMK Negeri 2 Kintamani.
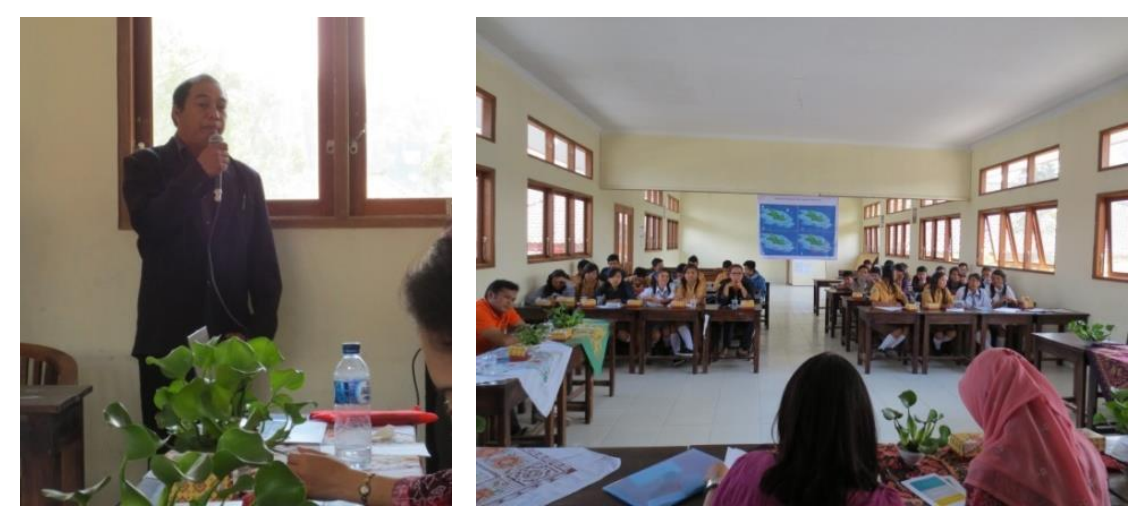

Gambar 3.1. Pembukaan kegiatan penyuluhan oleh Kepala Sekolah SMK Negeri 2

Acara penyuluhan yang bertempat di SMK Negeri 2 Kintamani dibuka oleh Bapak Kepala Sekolah (Gambar 3.1). Beliau menyambut baik kegiatan penyuluhan yang berkaitan langsung dengan 
permasalahan yang sering dihadapi oleh pembudidaya ikan nila di KJA, dan beliau menambahkan bahwa materi pernyuluhan merupakan informasi yang berguna untuk siswa SMK, karena sekolah tersebut juga memiliki KJA yang digunakan untuk praktek lapangan. Bahkan beberapa guru tertarik untuk melakukan penelitian tentang penanganan penyakit jamur yang sering menyerang telur ikan menggunakan herbal. Bapak Kepala Sekolah menyambut baik apabila diadakan kegiatan serupa dan menawarkan tempat pelaksanaan kegiatan di sekolah SMK Negeri 2 Kintamani. Beliau berharap dengan kegiatan yang melibatkan Fakultas Kelautan dan Perikanan (FKP) dan SMK Negeri 2, akan mendorong siswa untuk termotivasi melanjutkan kuliah di FKP Universitas Udayana.
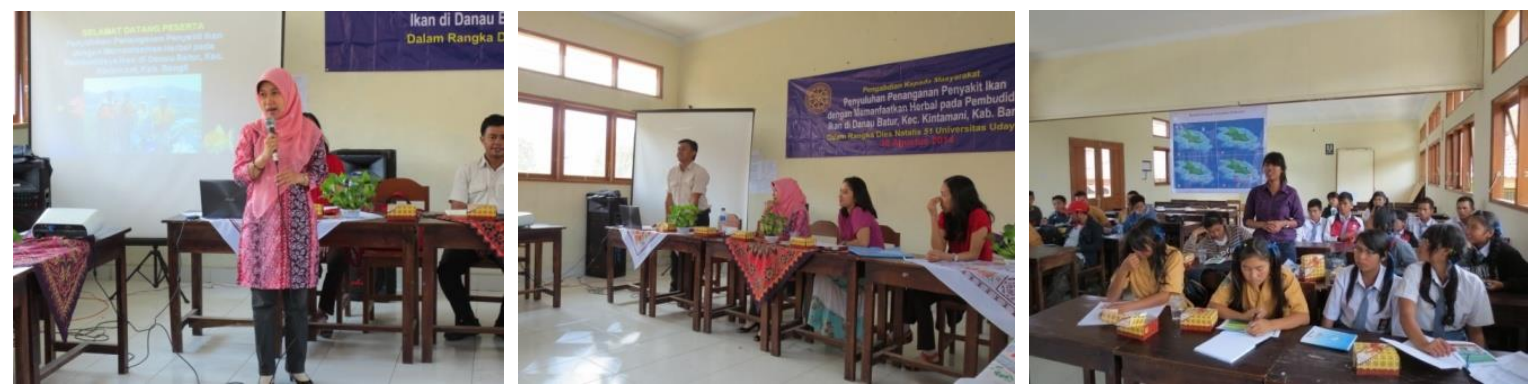

Gambar 3.2. Pemaparan materi dan diskusi dengan peserta penyuluhan

Penyuluhan tentang pengobatan penyakit ikan nila menggunakan herbal terlaksana dengan baik (Gambar 3.2). Pembudiya ikan pada umumnya belum mempunyai pemahaman jenis-jenis herbal yang bisa digunakan untuk pencegahan dan pengobatan penyakit ikan nila. Pada umumnya pembudidaya belum bisa membedakan gelaja klinis penyakit yang menyerang ikan nila, apakah disebabkan oleh jamur, bakteri, virus, maupun karena pakan yang rusak. Pembudidaya ikan nila dan siswa SMK antusias menanyakan jenis herbal, dosis, dan aplikasi penggunaaan untuk mengobati dan penyakit ikan. Penanganan penyakit ikan menggunakan herbal sangat mudah diaplikasikan karena kunyit, bawang putih, sirih dan daun pepaya dapat diperoleh dengan mudah, dan harga yang terjangkau oleh pembudidaya. Materi penyuluhan meliputi: penjelasan tentang penyakit utama pada ikan nila, stadia ikan nila terserang penyakit, jenis dan fungsi herbal, keuntungan menggunakan herbal, penggunaan herbal (dosis dan aplikasi) untuk pencegahan dan pengobatan. Selain memaparkan materi menggunakan infokus, kegiatan penyuluhan juga disosialisasikan dengan penyebaran leaflet (Gambar 3.3) untuk pembudidaya ikan dan siswa SMK. Setelah sesi tanya jawab acara ditutup dengan review mengenai hal-hal penting yang perlu diketahui tentang penyakit pada ikan nila, cara pencegahan dan pengobatan menggunakan herbal.
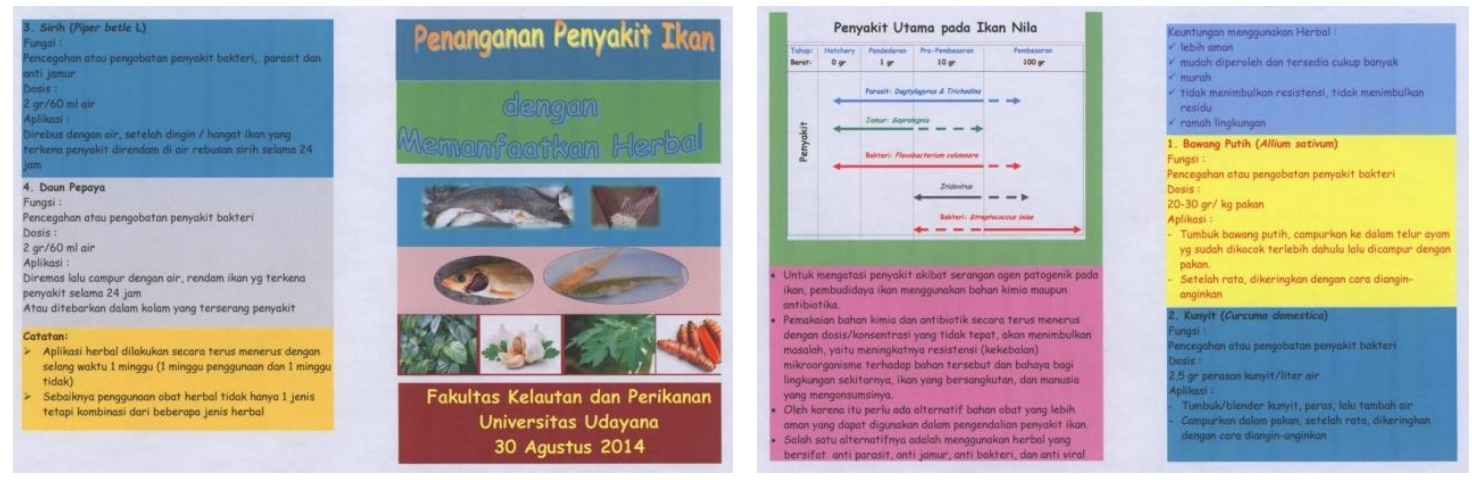

Gambar 3.3. Leaflet yang dibagikan pada peserta penyuluhan 


\section{KESIMPULAN DAN SARAN}

\subsection{Kesimpulan}

Kegiatan penyuluhan telah berhasil dan berjalan dengan baik, yaitu memberikan informasi kepada pembudidaya ikan nila di Danau Batur mengenai pencegahan dan penanganan penyakit ikan menggunakan herbal. Hasil kegiatan menunjukkan $90 \%$ peserta memahami materi yang diberikan Keberhasilan ditunjukkan dengan adanya respon positif dari peserta, dengan mengajukan berbagai pertanyaan dan tanggapan yang diberikan selama sesi tanya jawab dan adanya keinginan untuk mempraktekkan pengetahuan tersebut.

\subsection{Saran}

Diperlukan kontinuitas penyuluhan dan aplikasi penggunaan herbal secara langsung pada pembudidaya ikan nila untuk meningkatkan produktivitas budidaya ikan nila di Danau Batur.

\section{UCAPAN TERIMA KASIH}

Ucapan terima kasih disampaikan pada Lembaga Penelitian dan Pengabdian Kepada Masyarakat (LPPM) Universitas Udayana, atas dana pengabdian yang bersumber dari PNBP tahun 2014. Ucapan terima kasih juga kepada pembudidaya ikan di Danau Batur, atas partisipasinya, serta segenap keluarga besar SMK Negeri 2 Kintamani yang mendukung kegiatan ini.

\section{DAFTAR PUSTAKA}

Alderman, DJ. 2004. Control of Oomycetes pathogen in aquaculture. In Salmon Saprolegniasis. Muller GJ. Editor. Boneville Power Administration, Portland.

Fakhrizal, A., Rahmaniah, E., Inayah, T. 2010. Pengaruh Ekstrak Bawang Putih Dengan Dosis Yang Berbeda Terhadap Mortalitas Kutu Ikan (Argulus Sp.) Yang Menginfeksi Ikan Mas Koki (Carassius Auratus Linn). Jurusan Budidaya Perairan, Universitas Lambung Mangkurat, Banjarbaru.

Haryati, A., Grandiosa, R., Dwi, I., Santika, A. 2012. Uji Efektivitas Daun Pepaya (Carica papaya) untuk Pengobatan Infeksi Bakteri Aeormonas hydrophila Pada Ikan Mas Koki (Carasius auratus). Fakultas Perikanan dan Ilmu Kelautan. Unpad.

Kordi, G.2009. Budidaya Perairan. Penerbit PT Citra Aditya Bakti. Bandung

Lengka, K., Manoppo, H., Magdalena. 2013. Peningkatan Respon Imun Non Spesik Ikan Mas (Cyprinus carpio L) Melalui Pemberian Bawang Putih (Allium Sativum). Jurnal Budidaya Perairan Mei 2013. Vol 1 No $2: 21-28$ 